\title{
Bone Marrow Transplantation and Medical Tourism at Erciyes University - A Single Center Experience
}

\author{
Nicolette Leonie Tiren-Verbeet ${ }^{1}$, Mustafa Cetin ${ }^{1}$, Emine Alp ${ }^{2}$, Mehmet Doganay ${ }^{2 *}$ \\ ${ }^{1}$ Department of Hematology, Faculty of Medicine, Erciyes University, Kayseri, Turkey \\ ${ }^{2}$ Department of Infectious Diseases and Clinical Microbiology, Faculty of Medicine, Erciyes University, Kayseri, Turkey
}

Corresponding Author: Mehmet Doganay, MD, Professor of Infectious Diseases, Department of Infectious Diseases, Faculty of Medicine, Erciyes University, 38039, Kayseri, Turkey. Tel: +90 533368 2042, Email: mdoganay@erciyes.edu.tr

Received October 10, 2017; Accepted November 17, 2017; Online Published January 20, 2018

\begin{abstract}
Medical tourism emerged when people were challenged with high costs and slow service in medical care. As a consequence of these issues, people started to look for medical treatment in other countries. Globalization accelerated the growth of medical tourism. Several "push" and "pull" factors play roles in the motivation of patients to become a medical tourist. This review addresses the different aspects of medical tourism in general, describes the development of medical tourism in Turkey, and describes experiences with medical tourism in the Bone Marrow Transplantation Center (BMTC) at Erciyes University, Kayseri, Turkey. Since January 2016, an international collaboration has existed between BMTC and the King Hamed University Hospital (KHUH) in Bahrain. Ten allogeneic stem cell transplantations (SCTs) have been performed on patients from Bahrain with acute lymphoblastic leukemia (ALL), acute myeloid leukemia (AML), Hodgkin lymphoma, and myelofibrosis. Furthermore, ten autologous SCT have been conducted on patients from Bahrain with multiple myeloma (MM), Hodgkin lymphoma (HL), and non-Hodgkin lymphoma (NHL). In 2016, transplant-related mortality (TRM) at 100 days among Bahrain patients was $0 \%$ compared to $2.6 \%$ in all patients. Although these numbers are small, the first results show that the outcomes of international patients are similar to those of non-international patients. In our experience, the key to a successful collaboration between international hospitals is having close communication regarding the treatment of the international patient. The outcome of a large group of international compared with non-international patients should be further studied.

Keywords: Medical Tourism, Health Tourism, Bone Marrow Transplantation
\end{abstract}

Citation: Tiren-Verbeet NL, Cetin M, Alp E, Doganay M. Bone marrow transplantation and medical tourism at Erciyes University - A single center experience. Int J Travel Med Glob Health. 2018;6(1):1-6. doi:10.15171/ijtmgh.2018.01.

\section{Introduction}

In its broadest meaning, medical tourism refers to "travel across international borders to receive some form of medical treatment." 1 Medical tourism emerged in the 1990s when people in developed countries were challenged with high costs and slow service in medical care. As a consequence, people started to look for medical treatment in other countries. ${ }^{2}$ Globalization, including cheap and widely available air travel, and easy, cross-border marketing by medical providers accelerated the growth of medical tourism. ${ }^{3}$ The terms "medical tourism" and "health tourism" are used interchangeably. "Health tourism" is defined by the World Health Organization (WHO) as the use of services that improve physical or psychological health with the help of mineral water springs, climatic conditions, or medical intervention in an area outside one's place of residence for more than 24 hours and less than one year. ${ }^{5}$ Medical tourism is combined with thermal tourism, elderly tourism, and disabled tourism as a part of health tourism. ${ }^{6}$

The current review addresses the different aspects of medical tourism in general, describes the development of medical tourism in Turkey, and describes experiences with medical tourism in the Bone Marrow Transplantation Center (BMTC) in Erciyes University, Kayseri.

\section{General Considerations on Medical Tourism}

Several "push" and "pull" factors play roles in the motivation of patients to become a medical tourist. ${ }^{7-9}$ The push factors, factors that drive people abroad, are high costs, long waiting periods, and lack of insurance in their homeland. ${ }^{10}$ Pull factors, factors that attract people to medical tourism destinations, may include high quality, similar language, and same religion and culture.

\section{Barriers to Medical Tourism}

As described by Rokni et al, one of the main barriers to the

Copyright $\odot 2018$ The Author(s). This is an open-access article distributed under the terms of the Creative Commons Attribution License (http:// creativecommons.org/licenses/by/4.0), which permits unrestricted use, distribution, and reproduction in any medium, provided the original work is properly cited. 
development of medical tourism concerns policy making and government regulations (Figure 1). ${ }^{11}$ By establishing a centralized system for promotion and training and reconfiguring goals, a country's approach can be standardized and its position in the medical tourism industry thereby strengthened. A second barrier may be the communication skills of the professional health team in addressing a patient's perspective and cultural differences. Foreign language, which makes the medical tourist vulnerable to miscommunication, is the third factor that can complicate the success of medical tourism. Furthermore, expertise is essential. Specialists who have received special training in working with international patients are necessary. Two factors contributing to the success of medical tourism are (a) promotion through overseas marketing strategies and (b) research and development activities. A facility should distinguish itself to attract foreign patients, because the same quality can be found in some other countries. Medical tourism can be economically beneficial due to its direct effect; its secondary effect is the spending of the medical tourist and his family or other company. Unfortunately, it can also have an opposite effect, as has been described for the situation in South Korea; the government of South Korea has invested more than \$US400 million annually, while the number of medical tourists is showing a decreasing trend. ${ }^{11}$

In addition to these barriers, concerns have been raised regarding post-procedure health care. ${ }^{12}$ Costs rise when medical tourists return with complications. The data existing at the present time is insufficient; however, analysis in the United Kingdom has indicated that, if handled correctly, medical tourism can have possible financial savings in future health care and social costs. ${ }^{13}$ Further research and monitoring of the direct and indirect impacts of medical tourism on the economy should shed more light on this matter. In addition, international collaboration between countries with inbound and outbound medical tourists could improve not only the financial benefits, but also the quality of pre- and postmedical treatment care of medical tourists. ${ }^{14}$

\section{Medical Tourism in Turkey}

In Turkey, in parallel with the Health Transformation Program, health tourism has rapidly developed in the last ten years. ${ }^{15-17}$ Both public and private hospitals offer high quality services with the latest technology and highly qualified personnel. Forty-nine health care institutions have been accredited by the Joint Commission International (JCI) in Turkey, one of the highest rates in the region. ${ }^{18}$ According to the Evaluation Report on Medical Tourism in Turkey, 2013, approximately 300000 medical tourists visit Turkey annually. Two goals of the Health Development Program within Turkey's Tenth Development Plan, 2014-2018 include (a) to treat 750000 foreign medical patients, and (b) to earn \$US56 million in medical tourism. To achieve this, the program consists of 4 components: Development of Corporate and Legal Infrastructure for Health Tourism, Improvement of Physical and Technical Infrastructure in Medical Tourism, Enhancement of Service Quality in Health Tourism, Effective Advertising and Marketing in Health Tourism. ${ }^{19}$ By addressing these items, the barriers mentioned above could be avoided. The results of this program will be evaluated after 2018 .

Among 30 medical tourism destinations, Turkey is ranked 14th in the Medical Tourism Index..$^{20}$ In 2013, an evaluation of medical tourism in Turkey was reported by Turkey's Ministry of Health. ${ }^{19}$ In this report, the origin, purpose, preference, and other factors of international patients who received health care services were analyzed. The results showed that medical tourists preferred locations where traditional tourism already existed and cities where the infrastructure of health care services was good. Also, health care services producing at international standards and achieving JCI standards are clustered, and direct flights already land there. The most preferred cities were Antalya and Istanbul. Private hospitals were preferred by $91 \%$ of medical tourists, whereas government hospitals and university hospitals only received $9 \%$ of the medical tourists. Most of the medical tourists came from Libya, Germany, and Iraq. This data should be taken into consideration when planning and coordinating medical tourism.

A note should be made regarding one special group of medical tourists: those patients receiving services under a bilateral agreement on health, and therefore receiving health care abroad under their health insurance. In this respect, Turkey's Ministry of Health has made bilateral agreements on health with countries including Sudan, Afghanistan, Yemen, Albania, Azerbaijan, and Bahrain..$^{21}$ From these countries, a certain number of patients come to Turkey to receive treatment under a relevant protocol by the Ministry of Health. These patients are sent to public or university hospitals by an

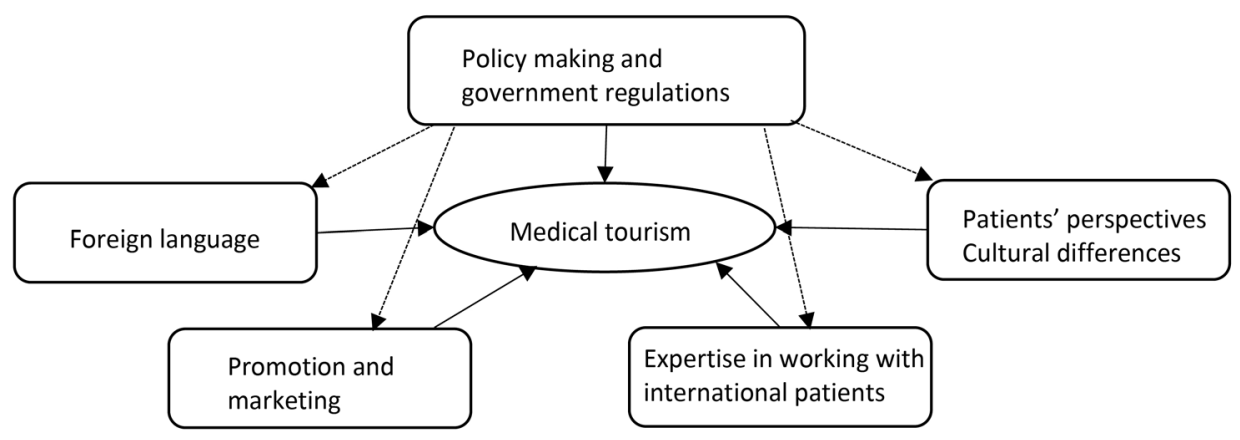

Figure 1. Obstacles of Medical Tourism (adapted from Rokna et al ${ }^{11}$ ). 
official letter from the General Directorate. Our experience at Erciyes University Bone Marrow Transplantation Center falls under this arrangement.

\section{What Is Bone Marrow Transplantation?}

Bone marrow transplantation is a medical procedure to replace damaged or destroyed bone marrow cells with healthy bone marrow. ${ }^{22,23}$ Bone marrow produces stem cells, immature cells that can produce all types of blood cells. At the present time, peripheral stem cell transplantation (SCT) is more commonly performed than bone marrow transplantation. ${ }^{24,25}$ Peripheral SCT is a procedure in which stem cells are collected from the peripheral blood after mobilization from the bone marrow with granulocyte-colony-stimulating factor (G-CSF), a growth factor. ${ }^{26}$ There are two types of SCT. First, there is autologous SCT, in which stem cells previously collected from the patient himself are given back after high-dose chemotherapy as a "stem cell rescue". ${ }^{27}$ Secondly, allogeneic SCT is a procedure in which mobilized stem cells from a healthy donor are given to a patient to evoke an immune response in the patient to cure a hematological cancer. ${ }^{28}$ Patients can be pretreated with either a myeloablative regimen with chemotherapy with or without radiotherapy or a reduced intensity regimen. ${ }^{29}$ Indications for an autologous SCT are multiple myeloma (MM), relapsed non-Hodgkin lymphoma (NHL), or Hodgkin lymphoma (HL). ${ }^{30-33}$ Sometimes, solid tumors such as in testis carcinoma, breast cancer, or autoimmune diseases such as systemic scleroderma are also indications for autologous transplantation. ${ }^{34-37}$ Indications for allogeneic SCT are either

(A)

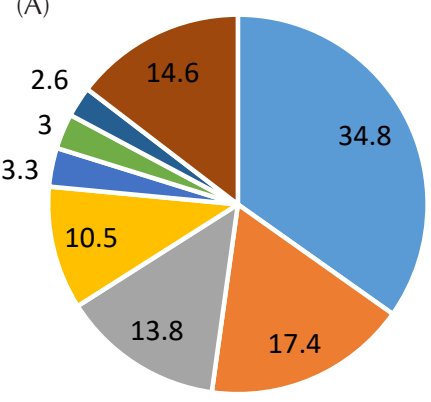

$=\mathrm{AML}$
$-\mathrm{ALL}$
$=\mathrm{MDS} / \mathrm{MPN}$
$-\mathrm{NHL} / \mathrm{HL}$
$=\mathrm{CML}$
$=\mathrm{PCD}$
$-\mathrm{CLL}$
$=$ others

3.8

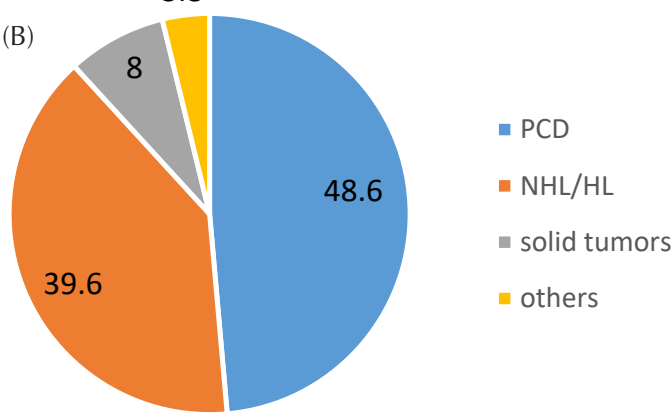

Figure 2. Indications of Allogeneic (A) and Autologous (B) Stem Cell Transplantations (adapted from Niederwieser et $\mathrm{al}^{43}$ ). Abbreviations: AML: acute myeloid leukemia, ALL: acute lymphoblastic leukemia, MDS/ MPN: myelodysplastic syndrome/myeloproliferative disease, NHL/HL: non-Hodgkin lymphoma/Hodgkin lymphoma; CML: chronic myeloid leukemia, PCD: plasma cell disorders, CLL: chronic lymphatic leukemia. benign such as severe aplastic anemia or sickle cell disease and thalassemia or malignant hematological diseases. ${ }^{38-42}$ Acute myeloid leukemia (AML) and acute lymphoblastic leukemia (ALL) are the most common indications, as shown in Figure $2 .{ }^{43}$

\section{Our Experience With Bone Marrow Transplantation and Medical Tourism}

Erciyes University was established in 1978. Today, it consists of 19 faculties, 20 vocational schools, and 32 research centers. Almost a million patients are treated annually in Erciyes University Hospital. In the Hematology and Oncology Clinic, approximately 50000 and 5000 patients are treated annually in the outpatient and inpatient clinic, respectively. In our center, we perform more than 100 allogeneic and autologous hematopoietic transplantations are performed annually. ${ }^{44,45}$ In the Erciyes University BMTC, more than 700 autologous and more than 500 allogeneic SCTs have been conducted with JACIE Accreditation (Joint Accreditation CommitteeISCT \& EBMT; ISCT: International Society for Cellular Therapy; EBMT: European Society for Blood and Marrow Transplantation). ${ }^{46}$ Since 2016, an international collaboration has existed between Erciyes University and the King Hamed University Hospital (KHUH) in Bahrain. Since January 2016, 10 allogeneic SCTs and 10 autologous SCTs have been performed on international patients from Bahrain, as shown in Figure 3. Indications for allogeneic SCTs were: ALL (5 patients), AML (3 patients), HL (1 patient), and myelofibrosis (1 patient). Indications for autologous SCTs were: MM (6

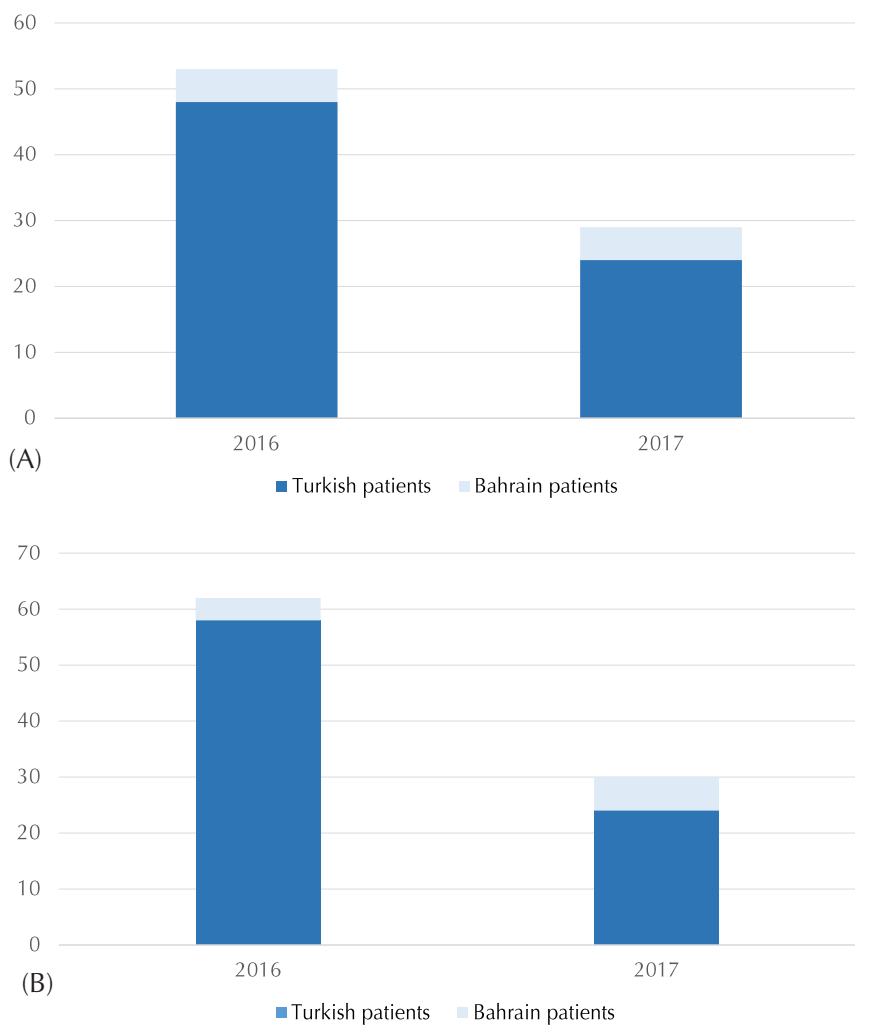

Figure 3. Total Number of Allogeneic (a) and Autologous (b) Stem Cell Transplantations and Number of International Transplant Patients Since 2016 
patients), HL (1 patient), and NHL (1 patient). Before referral, a committee consisting of hematologists from our center and hemato-oncologists from $\mathrm{KHUH}$ approved the indication for autologous or allogeneic SCT. After a thorough pre-transplant procedure including a recent remission status of the disease, an assessment of cardiopulmonary status, and an assessment of mental status, the transplantation procedure could continue. When a patient was not in remission or had severe co-morbidities, close communication with $\mathrm{KHUH}$ regarding the further treatment plan of the patient was maintained. For all referred patients, close and regular communication was maintained between the center and KHUH. After discharge from the clinic, patients were closely monitored in our outpatient clinic. Depending on the clinical status, patients were sent to Bahrain varying from a few weeks to a few months after discharge. At all times during admission and also in the outpatient clinic, several translators were available. In 2016, transplant-related mortality (TRM) at 100 days among Bahrain patients was $0 \%$ compared to $2.6 \%$ in all patients. The TRM at 100 days for 2017 will be determined later. In total, 3 patients were re-admitted due to (expected) post-transplant morbidity. Although these numbers are relatively small, our first results show that the outcomes of these patients were similar to those of non-international patients. In our experience, the key to a successful collaboration between international hospitals is having close communication on the treatment plan of the international patient. Furthermore, a specialized team with knowledge on foreign patients is essential. Also, the continuing availability of medical translators is of utmost importance. ${ }^{47,48}$

\section{Conclusion}

Due to globalization, medical tourism has grown exponentially in the last decade. Several push and pull factors can be identified. Though medical tourism can have a huge beneficial impact on the economy of the hosting country, it can also have the opposite effect. Several barriers to medical tourism should be taken into account when making policy regarding the development of medical tourism. Further research should fill the gaps in indirect economic impact and implementation of earlier governmental policy, such as the results of the 4 components of the Turkey's Tenth Development Plan on the part of Health Tourism.

A brief remark on "publication bias" should be made regarding the current existing literature on the subject. ${ }^{49,50}$ A thorough literature search was made, but only articles in English were reviewed. It was noticed that literature from export countries emphasized the negative components of medical tourism, whereas import countries focused mostly on its positive aspects. As publications may not be equally presented in PubMed, one should be cautious not to develop a skewed view on the subject.

In our experience regarding medical tourists under the bilateral agreement of health, excellent medical treatment can be provided. The key to a successful collaboration between international hospitals is having close communication regarding the treatment plan of the international patient. Furthermore, a specialized team with knowledge on

\section{Review Highlights}

\section{What Is Already Known?}

In this review, different aspects of medical tourism are addressed in general and the development of medical tourism in Turkey is described.

\section{What This Study Adds?}

Our experiences with medical tourism in the Bone Marrow Transplantation Center in Erciyes University, Kayseri have been shared.

international patients is essential. Also, the continuing availability of medical translators is of utmost importance. The outcomes of a large group of international patients in comparison with non-international patients should be further studied.

\section{Authors' Contributions}

All authors significantly contributed towards this research.

\section{Conflict of Interest Disclosures}

All authors report no conflicts of interest.

\section{Ethical Approval}

Not applicable.

\section{Funding/Support}

None.

\section{Acknowledgments}

The authors would like to acknowledge all staff members of KHUH for their contributions in our collaboration. The authors would also like to thank Ahmet Yigit and Hasan Karaca on collecting the data of our transplantations.

\section{References}

1. Ramirez de Arellano AB. Patients without borders: the emergence of medical tourism. Int J Health Serv. 2007;37(1):193-198. doi:10.2190/4857-468g-2325-47uu.

2. Carrera P, Lunt N. A European perspective on medical tourism: the need for a knowledge base. Int J Health Serv. 2010;40(3):469-484. doi:10.2190/HS.40.3.e.

3. Hanefeld J, Smith R, Horsfall D, Lunt N. What do we know about medical tourism? A review of the literature with discussion of its implications for the UK National Health Service as an example of a public health care system. J Travel Med. 2014;21(6):410-417. doi:10.1111/jtm.12147.

4. Lunt N, Carrera P. Medical tourism: assessing the evidence on treatment abroad. Maturitas. 2010;66(1):27-32. doi:10.1016/j. maturitas.2010.01.017.

5. Amouzagar S, Mojaradi Z, Izanloo A, Beikzadeh S, Milani M. Qualitative Examination of Health Tourism and Its Challenges. Int J Travel Med Glob Health. 2016;4(3):88-91. doi:10.21859/ ijtmgh-040304

6. Crooks VA, Kingsbury P, Snyder J, Johnston R. What is known about the patient's experience of medical tourism? A scoping review. BMC Health Serv Res. 2010;10:266. doi:10.1186/14726963-10-266.

7. Masoud F, Alireza J, Mahmoud K, Zahra A. A systematic review of publications studies on medical tourism. J Educ Health Promot. 
2013;2:51. doi:10.4103/2277-9531.119037.

8. Jabbari A, Delgoshaei B, Mardani R, Tabibi SJ. Medical tourism in Iran: Issues and challenges. J Educ Health Promot. 2012;1:39. doi:10.4103/2277-9531.104809.

9. Mogaka JJ, Tsoka-Gwegweni JM, Mupara LM, MashambaThompson T. Role, structure and effects of medical tourism in Africa: a systematic scoping review protocol. BMJ Open. 2017;7(6):e013021. doi:10.1136/bmjopen-2016-013021.

10. Morciano C, Laricchiuta P, Taruscio D, Schunemann H. European Reference Networks and Guideline Development and Use: Challenges and Opportunities. Public Health Genomics. 2015;18(5):318-320. doi:10.1159/000435852.

11. Rokni L, Avci T, Park SH. Barriers of Developing Medical Tourism in a Destination: A Case of South Korea. Iran J Public Health. 2017;46(7):930-937.

12. Johnston R, Crooks VA, Snyder J, Kingsbury P. What is known about the effects of medical tourism in destination and departure countries? A scoping review. Int J Equity Health. 2010;9:24. doi:10.1186/1475-9276-9-24.

13. Hanefeld J, Horsfall D, Lunt N, Smith R. Medical tourism: a cost or benefit to the NHS? PLoS One. 2013;8(10):e70406. doi:10.1371/ journal.pone.0070406.

14. Crooks VA, Ormond M, Jin KN. Reflections on 'medical tourism' from the 2016 Global Healthcare Policy and Management Forum. BMC Proc. 2017;11(Suppl 8):6. doi:10.1186/s12919-017-0075-8.

15. De Neve JW, Dave R, Gurel M, Subramanian SV. International patients in a Turkish hospital: a quantitative study on cross-border health care at the intersection of Eastern Europe, Asia and the Middle East. World Hosp Health Serv. 2012;48(1):5-7.

16. Ucak $\mathrm{H}$. The relationship between the growth in the health sector and inbound health tourism: the case of Turkey. Springerplus. 2016;5(1):1685. doi:10.1186/s40064-016-3341-8.

17. Ozan-Rafferty ME, Johnson JA, Shah GH, Kursun A. In the words of the medical tourist: an analysis of Internet narratives by health travelers to Turkey. J Med Internet Res. 2014;16(2):e43. doi:10.2196/jmir.2694.

18. Woodhead A. Scoping medical tourism and international hospital accreditation growth. Int J Health Care Qual Assur. 2013;26(8):688702.doi:10.1108/ijhcqa-10-2011-0060.

19. Republic of Turkey, Ministry of Health, Directorate general of Health Services, Department of health tourism. Evaluation Report on Medical Tourism in Turkey. Ankara: Ministry of Health; 2013.

20. Fetscherin M, Stephano RM. The medical tourism index: Scale development and validation. Tour Manag. 2016;52:539-556. doi:10.1016/j.tourman.2015.08.010.

21. Lunt N, Horsefall D, Hanefeld J. Handbook on Medical Tourism and Patient Mobility. Northampton, MA: Edward Elgar Publishing Ltd; 2015. doi:10.4337/9781783471195.

22. Bortin MM. A compendium of reported human bone marrow transplants. Transplantation. 1970;9(6):571-587. doi:10.1097/00007890-197006000-00006.

23. Thomas E, Storb R, Clift RA, et al. Bone-marrow transplantation (first of two parts). N Engl J Med. 1975;292(16):832-843. doi:10.1056/nejm197504172921605.

24. Arat M, Arpaci F, Ertem M, Gurman G. Turkish Transplant Registry: a comparative analysis of national activity with the EBMT European Activity Survey. Bone Marrow Transplant. 2008;42 Suppl 1:S142-s145. doi:10.1038/bmt.2008.144.

25. Passweg JR, Baldomero $\mathrm{H}$, Bader $\mathrm{P}$, et al. Use of haploidentical stem cell transplantation continues to increase: the 2015 European Society for Blood and Marrow Transplant activity survey report. Bone Marrow Transplant. 2017;52(6):811-817. doi:10.1038/ bmt.2017.34.

26. Sirinoglu Demiriz I, Tekgunduz E, Altuntas F. What is the most appropriate source for hematopoietic stem cell transplantation? Peripheral stem cell/bone marrow/cord blood. Bone Marrow Res. 2012;2012:834040. doi:10.1155/2012/834040.

27. Armitage JO. The History of Autologous Hematopoietic Cell Transplantation. In: Thomas' Hematopoietic Cell
Transplantation.Oxford, UK: Wiley-Blackwell; 2009:8-14. doi:10.1002/9781444303537.ch2.

28. Little MT, Storb R. History of haematopoietic stem-cell transplantation. Nat Rev Cancer. 2002;2(3):231-238. doi:10.1038/ nrc748.

29. Gyurkocza B, Sandmaier BM. Conditioning regimens for hematopoietic cell transplantation: one size does not fit all. Blood. 2014;124(3):344-353. doi:10.1182/blood-2014-02-514778.

30. Mohty M, Harousseau JL. Treatment of autologous stem cell transplant-eligible multiple myeloma patients: ten questions and answers. Haematologica. 2014;99(3):408-416. doi:10.3324/ haematol.2013.096149.

31. Robinson SP, Boumendil A, Finel H, et al. Autologous stem cell transplantation for relapsed/refractory diffuse large B-cell lymphoma: efficacy in the rituximab era and comparison to first allogeneic transplants. A report from the EBMT Lymphoma Working Party. Bone Marrow Transplant. 2016;51(3):365-371. doi:10.1038/bmt.2015.286.

32. Staton AD, Langston AA. Autologous stem cell transplant: still the standard for fit patients with mantle cell lymphoma. Clin Lymphoma Myeloma Leuk. 2017;17s:S96-s99. doi:10.1016/j. clml.2017.02.021.

33. Myers RM, Hill BT, Shaw BE, et al. Long-term outcomes among 2-year survivors of autologous hematopoietic cell transplantation for Hodgkin and diffuse large b-cell lymphoma. Cancer. 2017. doi:10.1002/cncr.31114.

34. Mancardi G, Sormani MP, Muraro PA, Boffa G, Saccardi R. Intense immunosuppression followed by autologous haematopoietic stem cell transplantation as a therapeutic strategy in aggressive forms of multiple sclerosis. Mult Scler. 2017:1352458517742532. doi:10.1177/1352458517742532.

35. Mancardi GL, Sormani MP, Gualandi F, et al. Autologous hematopoietic stem cell transplantation in multiple sclerosis: a phase II trial. Neurology. 2015;84(10):981-988. doi:10.1212/ wnl.0000000000001329.

36. Schmoll HJ, Kollmannsberger C, Metzner B, et al. Long-term results of first-line sequential high-dose etoposide, ifosfamide, and cisplatin chemotherapy plus autologous stem cell support for patients with advanced metastatic germ cell cancer: an extended phase I/II study of the German Testicular Cancer Study Group. J Clin Oncol. 2003;21(22):4083-4091. doi:10.1200/jco.2003.09.035.

37. Nieto Y, Champlin RE, Wingard JR, et al. Status of highdose chemotherapy for breast cancer: a review. Biol Blood Marrow Transplant. 2000;6(5):476-495. doi:10.1016/S10838791(00)70019-X.

38. Ades L, Mary JY, Robin M, et al. Long-term outcome after bone marrow transplantation for severe aplastic anemia. Blood. 2004;103(7):2490-2497. doi:10.1182/blood-2003-07-2546.

39. Kassim AA, Sharma D. Hematopoietic stem cell transplantation for sickle cell disease: The changing landscape. Hematol Oncol Stem Cell Ther. 2017;10(4):259-266. doi:10.1016/j. hemonc.2017.05.008.

40. Tekgunduz E, Kaynar L, Goker H, et al. Retrospective analysis of adult patients with acute lymphoblastic leukemia undergoing allogeneic hematopoietic cell transplantation: A multicenter experience of daily practice. Transfus Apher Sci. 2016;54(1):4147. doi:10.1016/j.transci.2016.01.010.

41. Eroglu C, Pala C, Kaynar L, et al. Comparison of total body irradiation plus cyclophosphamide with busulfan plus cyclophosphamide as conditioning regimens in patients with acute lymphoblastic leukemia undergoing allogeneic hematopoietic stem cell transplant. Leuk Lymphoma. 2013;54(11):2474-2479. doi:10.310 9/10428194.2013.779691.

42. Kaynar L, Demir K, Turak EE, et al. TcRalphabeta-depleted haploidentical transplantation results in adult acute leukemia patients. Hematology. 2017;22(3):136-144. doi:10.1080/102453 32.2016.1238182.

43. Niederwieser D, Baldomero H, Szer J, et al. Hematopoietic stem cell transplantation activity worldwide in 2012 and a SWOT 
analysis of the Worldwide Network for Blood and Marrow Transplantation Group including the global survey. Bone Marrow Transplant. 2016;51(6):778-785. doi:10.1038/bmt.2016.18.

44. Metan G, Kaynar L, Yozgat N, et al. A change for the antibacterial treatment policy to decrease carbapenem consumption at a haematopoietic stem cell transplantation centre. Infez Med. 2017;25(1):33-37

45. Demiraslan H, Cevahir F, Berk E, Metan G, Cetin M, Alp E. Is surveillance for colonization of carbapenem-resistant gramnegative bacteria important in adult bone marrow transplantation units? Am J Infect Control. 2017;45(7):735-739. doi:10.1016/j. ajic.2017.01.006.

46. Snowden JA, McGrath E, Duarte RF, et al. JACIE accreditation for blood and marrow transplantation: past, present and future directions of an international model for healthcare quality improvement. Bone Marrow Transplant. 2017;52(10):1367-1371. doi:10.1038/bmt.2017.54.

47. Ali PA, Johnson S. Speaking my patient's language: bilingual nurses' perspective about provision of language concordant care to patients with limited English proficiency. J Adv Nurs. 2017;73(2):421-432. doi:10.1111/jan.13143.

48. Flores G. The impact of medical interpreter services on the quality of health care: a systematic review. Med Care Res Rev. 2005;62(3):255-299. doi:10.1177/1077558705275416.

49. Easley TJ. Medical Journals, Publishers, and Conflict of Interest. Jama. 2017;317(17):1759-1760. doi:10.1001/jama.2017.3421.

50. Ahmed I, Sutton AJ, Riley RD. Assessment of publication bias, selection bias, and unavailable data in meta-analyses using individual participant data: a database survey. Bmj. 2012;344:d7762. doi:10.1136/bmj.d7762. 